\title{
Europe's Dystopian Futures: Perspectives on Emerging European Dystopian Visions and Their Implications
}

\author{
Martin Westlake \\ Correspondence: Visiting Professor in Practice, European Institute, London School of Political and Economic Science, \\ Houghton Street, London WC2A 2AE, United Kingdom. E-mail: m.westlake@1se.ac.uk
}

Received: September 16, 2020

Accepted: October 22, 2020 Online Published: November 11, 2020

doi:10.5539/res.v12n4p20

URL: https://doi.org/10.5539/res.v12n4p20

\begin{abstract}
The essay briefly charts how Europe first emerged as a concept, leading gradually to visions about its future, increasingly informed by practical federal and confederal models elsewhere. In literary terms, Europe's emerging dystopians rarely placed their visions in projected European futures, whether political or geographical. However, as post-war Europe has become increasingly integrated and as European organisations - particularly the European Union (EU) - have become increasingly well-established, so literary dystopian depictions of 'Europe' and 'Brussels' have duly started to emerge. Brief consideration of three case studies reveals recurring themes that suggest Europeans' worst fears about their futures are the returns, in some form, of their pasts.
\end{abstract}

Keywords: European integration, European Union, dystopias, dystopian literature

\section{Introduction}

\subsection{What This Essay Will Seek to Do}

'Europe' is a relatively recent concept and an even more recent political and organisational phenomenon, and its most-advanced integration process, the post-war European integration process leading to the current European Union (EU), is only some seventy years old. Nevertheless, as this essay will consider, dystopian literary visions about Europe's future have gradually been emerging - an indication that the EU is considered an organisation sufficiently well-established for such literary visions to be, in some sense, plausible. The underlying assumption of this essay is that dystopian literature, as it emerges, can be a significant indicator of how a society is evolving, particularly in terms of self-perceptions. (Prestwick House, 2015) What, then, might the nature of those visions reveal about the way Europeans see themselves?

This essay will describe how Europe emerged as an idea and how, once that concept had been consolidated, various visions about the continent's future were generated. These early federalist visions were increasingly informed by the emergence of real federal and confederal models. At the same time, trade and industry and technological advances led increasingly to the creation of European organisations and hence of an organised Europe. Towards the end of the nineteenth and beginning of the twentieth centuries, the emergence of mechanised warfare, and the massive human and economic toll it took, led to a new, moral imperative for European federal visions.

Pre-1939 literature, meanwhile, generated plenty of dystopian visions, but few, if any, about Europe itself, or even geographically located in Europe. It was only in the 1980s, when the federal vision had at last been translated into a practical and enduring process, and a consolidating European Community (soon to become the EU) had started to extend membership to further European countries, that fiction specifically about Europe and the EU began to emerge. The essay charts this emergence and considers three examples as case studies. The essay concludes by considering to what extent these literary visions share motifs, and what those shared motifs reveal about current European preoccupations.

\subsection{Caveats and Definitions}

This essay adopts a non-empirical, qualitative approach. It is based on a selective, and far from comprehensive, survey of mostly, though not exclusively, English-language literature, concentrating in particular on the post-1945 period. Its purpose is to explore cultural trends and suggest their significance. Its conclusions are necessarily speculative. The intention is to encourage reflection and further discussion rather than to draw hard conclusions.

The definitions of a number of terms employed in the essay are largely based on those established by Lyman Tower Sergent (2016), namely:

'Utopia' - 'a non-existent society described in considerable detail and normally located in time and space'; 
'Eutopia' - 'a non-existent society described in considerable detail and normally located in time and space that the author intended a contemporaneous reader to view as considerably better than the society in which that reader lived';

'Dystopia'; - 'a non-existent society described in considerable detail and normally located in time and space that the author intended a contemporaneous reader to view as considerably worse than the society in which that reader lived';

'Utopian satire'; - 'a non-existent society described in considerable detail and normally located in time and space that the author intended a contemporaneous reader to view as a criticism of that contemporary society'.

The essay also uses the term 'Uchronia', coined by Charles Renouvier (1876), and created by replacing the 'topos' (place) of 'Utopia' with 'chronos' for time, thus creating the meaning, 'no time'. A Uchronia is essentially a hypothetical or fictional time period before the present or running in parallel with the present. It is built out of recognisable components and can therefore seem authentic.

\section{The Emergence of Europe}

\subsection{The Emergence of an Idea}

For European futures to exist, Europe had first to exist. There was a time when it did not, whether culturally, politically, geographically or even geologically; the lands of the Cretaceous period, some eighty million years ago, did not correspond at all with the modern European landmass. (Flannery, 2019, pp. 9-13) Ultimately, geology gave Europe its boundaries. Thus, now 'Europe extends from Ireland in the west to the Caucasus in the east, and from Svalbard in the north to Gibraltar and Syria in the south' (ibid., p. 3). But, for a long time, even once there was a continent and there were peoples upon it, there was no sense of an entity or of any commonality whatsoever.

In his seminal work, Europe: The Emergence of an Idea (1957), Denys Hay explored how an ancient Greek myth (Europa and the bull) slowly became a concept and, finally, an entity. Hay argued that the development of the European idea in the Middle Ages could be traced back to the clash between Greek civilisation and the Persians. The latter, as the 'other', encouraged a common sense of what it was to be Greek, thus stimulating the Greek unification process. Persia morphed over time into Asia. 'By the fifth century (B.C.),' Hay recounts, "“Asiatic” was firmly linked with concepts of lavish splendour, of vulgarity, of arbitrary authority, of all that was antithetical to Greece and Greek values.' (Hay, 1957, p. 3) Already, the southern part of the European continent, and particularly the south-east, with its favourable mixture of geography and climate, had induced a sense of superiority in its inhabitants, relative to those living further south on the African continent.

Hay showed the way this tripartite division between Europe, Asia and Africa was gradually consolidated through successive interpretations of the Old Testament's account, in the book of Genesis, about how the earth was peopled after the great flood. In the fifth century A.D., St Augustine took everything much further by imaginative interpretations of the Hebrew names of Noah's three sons, Ham, Shem and Japheth. Asia became the land of Shem. Europe became the land of Japheth and the gentiles. And Africa became the land of Ham, who 'surely signifies the hot brand of heretics', thus further identifying the African peoples as being inferior and evil. Indeed, St Augustine argued that all the descendants of Ham were heretics (ibid., p. 12). St Augustine's interpretation almost certainly corresponded to already existing prejudices, but as Christianity gradually extended throughout the Continent, increasingly corresponding to its geographical confines, his interpretation, reinforced by succeeding theologians, further consolidated an already inherent sense of superiority, but also of territoriality.

However, 'nothing,' Hay argued, 'did more to compel a specifically territorial view of Christianity than the vigour and success of Moslem attacks during the three hundred years that lay between the death of the Prophet in 632 and the break-up of the united Caliphate in the ninth and tenth centuries' (ibid., p. 24). Just as the Persian threat had helped consolidate a Greek sense of identity and territory, so the Moslem threat consolidated a common sense of Christian identity and territory; widespread Christianity had become Christendom. And so, 'After the fall of Rome, the religious hierarchy was at pains to point to barbarianism as the antithesis of civilisation, thus contributing to a growing feeling of belonging - an almost racial feeling - amongst those in Christendom.' (European Parliament, 2020)

This innate sense of superiority would justify the Crusades and early colonisation, with Christendom and/or Christianity seeing its vocation in evangelising the inferior world(s) around it. From the fifteenth century onwards, cartography helped also to consolidate the notion of Christendom as a territorial entity but also, increasingly, 'the virtual identity of Christendom and Europe.' (Hay, 1957, p. 94) Christendom was, if not in decline, then in stasis: 'Given a universal church that was universal no longer - in Europe, let alone over a wider area - and which was struggling ineffectively to protect European Christendom from outside attack... the stage was set for the gradual emergence of a notion of Europe which would slowly evict Christendom from its hardly won place as an integrating notion. Europe was to be a less ambitious project than Christendom, but hardly less influential.' (Ibid., p. 95)

An elision had occurred, so that the attributes of Christendom became those of Europe. Thus, Europe was non-Muslim, 
non-African, non-Barbarian, non-Pagan and non-anarchic. Europe was, contrarily, white, Christian, organised, rational, hierarchical, prosperous and superior. Previously Europe had become Christian. Now Christianity had become European. In 1625 Samuel Purchas could write, in all seriousness, that Jesus Christ was, 'almost wholly and only Europaean,' (ibid., p. 120) and that 'The Qualitie of Europe exceeds her Quantitie, in this the least, in that the best of the World.' By 1796, Edmund Burke could write that, 'No European can be a complete exile in any part of Europe.' (Ibid., p. 123) By the eighteenth-century Europeans, 'are familiar with the term, and indeed are once more setting out into the world, to conquer territories for Europe ... and European industry and commerce thrive.' (European Parliament, 2020)

\subsection{The Emergence of Visions}

It is no coincidence, then, that Europeans, who now recognised themselves as such, started in that period to dream about how a future Europe might be organised politically and economically. These thinkers were strongly motivated by the desire to avoid the sort of internecine warfare that periodically inflicted so much damage on Europe's populations and fabric. William Penn (1644-1718) was an early such thinker who grew up in the long shadow cast by the aftermath of the 1618-48 Thirty Years War. In 1693 he published an 'Essay towards the Present and Future Peace of Europe, by the Establishment of an European Dyet, Parliament or Estates.' (See Salmon \& Nicoll, 1997, pp. 3-6) Penn's idea, which came far before its time, was for Europe's leaders to meet periodically in a general diet in order to discuss and settle differences that could not be resolved by standard diplomacy ('private embassies'). His proposal that, 'To avoid quarrel for precedency, the room may be round, and have diverse doors to come in and go out at, to prevent exceptions,' (ibid., p. 5) would be familiar to any modern-day leader of an EU Member State attending a European Council meeting! Penn's proposal was a precursor of what was to become a steady stream of such visions, as Table 1 illustrates.

Table 1. The Emergence of Visions - some examples

\begin{tabular}{|c|c|}
\hline William Penn (1693) & $\begin{array}{l}\text { A European Diet/Parliament (An essay towards the } \\
\text { present and future peace of Europe) }\end{array}$ \\
\hline Abbot Charles de Saint Pierre (1728) & $\begin{array}{l}\text { A European League of Sovereign States (Projet pour } \\
\text { rendre la paix perpétuelle en Europe) }\end{array}$ \\
\hline Immanuel Kant (1795) & $\begin{array}{l}\text { An Eternal Peace Congress (Perpetual Peace: A } \\
\text { Philosophical Sketch) }\end{array}$ \\
\hline Napoleon Bonaparte (1806) & $\begin{array}{l}\text { A Continental System/Customs Union/'the United } \\
\text { States of Europe' (St Helena interview) }\end{array}$ \\
\hline Wojciech Jastrzebowski (1831) & $\begin{array}{l}\text { The United States of Europe (About eternal peace } \\
\text { between the nations) }\end{array}$ \\
\hline Giuseppe Mazzini (1843) & $\begin{array}{l}\text { A Federation of European Republics ('Young } \\
\text { Europe' movement) }\end{array}$ \\
\hline Victor Hugo (1849) & $\begin{array}{l}\text { The United States of Europe (Speech at the } \\
\text { International Peace Congress, Paris) }\end{array}$ \\
\hline Mikhail Bakunin (1867) & $\begin{array}{l}\text { The United States of Europe (speech at the } 1867 \\
\text { Congress of Vienna) }\end{array}$ \\
\hline Theodore de Korwin Szymanowski (1885) & $\begin{array}{l}\text { The Future of Europe in Economic, Political and } \\
\text { Social Terms (including a single currency) } \\
\text { (polemical essay) }\end{array}$ \\
\hline
\end{tabular}

This stream of visionary thought would continue up to, and beyond, the major conflagration of the First World War, when it would mostly evolve into, or merge with, the growing family of European federalist visions. The main difference between these two streams was the fact that the pre-1914 visions were mostly more like thought experiments than practical proposals. With the exception of Napoleon, none of the pre-war thinkers was ever anywhere close to having the means to realise their visions. Rather, these visions were explorations (in Kant's and Jastrzebowski's cases, meticulously thought through) of what an organised, peaceful Europe might look like. 


\subsection{The Emergence of Models}

In the $19^{\text {th }}$ century, increasingly, European thinkers had models to which they could look and where they could seek inspiration. Some of these, indeed, were regarded almost as being laboratory experiments. This was particularly the case with the Northern Colonies and, once independence had been declared in 1776, the United States of America. But there were plenty of part-models closer to home. Napoleonic Europe necessarily contested with some of the practical challenges of a (partially) unified Europe, including a common legal code, a customs union and currency area (the Cisalpine Republic). Post-1815 Germany's 39 sovereign states underwent Confederation (Deutscher Bund) and then moved closer to union with the 1834 Zollverein (customs union). Switzerland finally equipped itself with a federal constitution in 1847-48. Italy unified in 1861 and achieved monetary union one year later. The Latin Monetary Union (1865) established a trading area with partially fixed exchange rates. And then, in 1867, the Austro-Hungarian Empire came into being, a multi-national, multi-ethnic, multi-lingual behemoth which, despite all its many flaws, was the most successful example of European integration before the advent of the post-Second World War European Union (EU). What all of these experiences showed, in their different ways, was that unions of component parts, with sometimes very different identities, could be brought about. (Because, for example, of Bosnia's Muslim population, the Austro-Hungarian Empire even recognised Islam as an official state religion.) Beyond cooperation and alliances, it was becoming clear, unions were possible.

\subsection{The Emergence of European Organisations}

At the same time, with industrial advances and growing intra-European trade, Europe was becoming more organised and, as it became more organised, so more European organisations came into being. For example, as the Rhine was tamed, through the building of canals and locks and the straightening of its course, so trade along its length increased. This necessitated some sort of agreement between the countries through which the Rhine flowed (Switzerland, Germany, France, the Netherlands). They needed to agree on matters such as navigation rules, maintenance of water levels and flows and, later, use and maintenance of lock gates. Thus, in 1815, the Central Commission for Navigation on the Rhine, the world's oldest existing international organisation, was established to deal with these issues, as it still deals with them today.

As rail networks spread within European countries, so inevitably national networks started to join up. The first rail border crossing took place on 6 November 1842 between Mouscron (Belgium) and Tourcoing (France). In 1843, the first international railway connection was established between Brussels and Cologne, via Liege and Aachen. By 1846, the first international connection between two capitals, Brussels and Paris, had been established. In 1860, a first international conference to discuss railway timetables took place in Munich. In 1872, in Cologne, on the basis of a Prussian proposal, the first European passenger train timetable conference was held, soon to be followed by the first European rolling stock management conference. These conferences would be held twice a year up until the outbreak of hostilities in 1914. (Anastasiadou, 2017, p. 164) Thus, as Paye has put it, the continent went from 'the 'railroadisation' of Europe to the 'Europeanisation' of railroads.' (Paye, 2010, p. 124) Postal services provide another example from the late nineteenth century, with the creation of the Universal Postal Union in Bern in 1874. (Of the 21 signatory countries to the Treaty, 19 were European.)

This growing interconnectedness and organisation between European states increasingly gave a sense of Europe as an entity. The continent was no longer a mere geographical expression (to borrow from Metternich). It was now, post-Congress of Vienna, a system of balance and counterbalance, of growing coordination and administration, between competing nation states and alliances in a post-Westphalian world.

\subsection{The Emergence of the European Federalists}

It would take two massive cathartic shocks before the continent of Europe tipped decisively towards models of permanent organisation and cooperation. But the first shock, the 1914-1918 war, had already shifted European visionaries away from seeing some sort of federal organisation of the Continent as desirable, and towards the realisation that such an arrangement was vital - from prescriptive thought experiment to moral imperative. Europe could not go on tearing itself to pieces, they believed (though it was to do so again in 1939-1945). 
Table 2. The Emergence of the European Federalists - some examples

\begin{tabular}{|ll|}
\hline Richard Coudenhove-Kalergi (1923) & Pan-Europa Union \\
Leon Trotsky (1923) & A Soviet United States of Europe \\
Josef Pilsudski (1920s) & 'Intermarium' (a Baltic Union) \\
Aristide Briand (1929) & A Federation of European Nations \\
Edouard Herriot (1931) & The United States of Europe \\
Altiero Spinelli (1942) & The United States of Europe \\
Jean Monnet (1943) & A Federation of a European Entity (Algiers \\
Winston Churchill (1946) & Memorandum) \\
Robert Schuman (1950) & A kind of United States of Europe (Zurich speech) \\
\hline
\end{tabular}

Table 2 provides a brief illustrative list of the emerging European federalists in the interwar and Second World War period. (See the remarkable compendium in Lipgens, 1985, Vols. $1 \& 2$, for many more.) It will be seen that these were not limited to Western democratic thought nor, indeed, to Western Europe. What distinguishes these figures from the visionary thinkers in Table 1 is that the federalists were now closer to the levers of power and further from the realms of pure theory. The moral imperative had to be practically realised. This shift to pragmatism and practicalities was best represented by Jean Monnet who, as Deputy Secretary General of the League of Nations (1919-1923) had seen how sovereign nation states and the unanimity principle for decision-making led to inaction and stagnation. Well-connected in political and economic circles, Monnet was never far from the reins of government. The question was how to use those connections effectively. His 1943 vocabulary, with its cautious use of the term 'a European entity' suggests that he was well aware that such an enterprise could only succeed if the politicians were on board. It is, in retrospect, no coincidence that Monnet's pragmatic proposal for a limited sectoral approach combined with pooled sovereignty succeeded, with the 1952 European Coal and Steel Community, where so many other, grander, visions had failed. As Hay put it, 'Paradoxically, it was in the disillusionment after the Second World War, and in a continent shorn of its former world importance, that attempts were made to give the idea of Europe a new and practical meaning, to turn the name for a region into a political programme.' (Hay, 1957, p. 127)

\section{The Emergence of European Dystopian Visions - but not About Europe}

Thomas More's Utopia (1516) effectively created not one, but two, literary genres; the eutopian, and the dystopian (arguably, More's Utopia was both). The dystopian form was particularly effective in exploring the potential disadvantages of scientific and industrial advances and, gradually, a European dystopian literature grew up, as illustrated in Table 3. More had himself placed his 'nowhere' far from Europe and, pre-1945, it is difficult to find a utopia or dystopian vision placed in, or about, Europe geographically or as an entity of some sort (though this is not in any way to argue that utopian and/or dystopian literature was somehow specific to Europe in the late nineteenth and early twentieth centuries). 
Table 3. The Emergence of the European Dystopias - some examples

\begin{tabular}{|ll|}
\hline Samuel Butler (1872) & $\begin{array}{l}\text { Erewhon (arguably a satirical Utopia about, inter } \\
\text { alia, the menace of intelligent machines) }\end{array}$ \\
Anthony Trollope (1882) & $\begin{array}{l}\text { The Fixed Period (obligatory euthanasia) } \\
\text { Terome K. Jerome (1891) }\end{array}$ \\
H.G. Wells (1899) & $\begin{array}{l}\text { When the Sleeper Awakes (plutocratic dictatorship) } \\
\text { E.M. Forster (1909) }\end{array}$ \\
The Machine Stops (subterranean mankind \\
Yevgeny Zamyatin (1924) \\
Aldous Huxley (1932) & $\begin{array}{l}\text { We (plutocratic dictatorship) } \\
\text { Brave New World (eugenics) }\end{array}$ \\
Aldous Huxley (1948) & $\begin{array}{l}\text { Ape and Essence (post-apocalyptic decadence and } \\
\text { depravity) }\end{array}$ \\
\hline
\end{tabular}

Indeed, few, if any, European dystopians chose Europe as their geographical backgrounds. For example, Trollope's 'Britannula' is a fictional island somewhere near New Zealand. H.G. Wells sticks close to London and the Home Counties. Huxley's Brave New World is set in an America, as is his Ape and Essence. Orwell's 1984 is set in the super-state of Oceania or, more precisely, 'Air Strip One' (aka Great Britain), and so on. Nor, until relatively recently, do any of Europe's dystopians take aim at its post-war integration projects. They could not extrapolate from an organised Europe, nor imagine ghastly ends for such a Europe, for the simple reason that, as a reality, it didn't (yet) exist. (True, Mark Mazower began his 2024 Governing the World: The history of an idea from 1815 to the present at the 1815 Congress of Vienna. The Congress was, indeed, the first occasion where representatives came together on a continental scale but, in the understanding of this article, the aim of the Congress was not to construct something new but, rather to allow the old to continue.)

\section{The Emergence of an Organised Europe}

However, an organised and steadily integrating Europe has existed now for over seventy years, as Table 4, listing the main organisations and the numbers of participating European countries in each case illustrates. The table does not show the various regional organisations (for example, the Nordic Council, the Benelux Union, the Organisation of Black Sea Cooperation, the Visegrád Group) nor those to which the EU belongs (the European Economic Area, the European Customs Union). Sovereignty-sharing organisations - primarily the European Union and NATO - have consolidated their roles. The expansion of membership and integration of the various European countries has continued apace. The 1989 fall of the Berlin Wall and the end of the Cold War gave the processes a massive boost. It is not just that an organised Europe exists; there is increasingly more of it. Citizens of the EU's eurozone now even have European money in their pocket (an old Napoleonic dream). So how is 'Europe' being depicted creatively?

Table 4. Main European Organisations and Numbers of Members

$\begin{array}{ll}\text { The Council of Europe (1948) } & 47 \text { (from } 10 \text { founder member countries) } \\ \text { The European Coal and Steel Community (1952) } & 6 \\ \text { The European Economic Community (1958) } & 6 \text { (rising to 12) } \\ \text { The European Free Trade Association (1960) } & 4 \text { (from } 7 \text { founder member countries) } \\ \text { The European Union (1993) } & 27 \text { (rising from 12) } \\ \text { The eurozone (1999) } & 19 \text { EU member states } \\ \text { The Schengen Area (1995) } & \begin{array}{l}26 \text { European countries, including 22 EU member } \\ \text { states }\end{array} \\ \text { The Organization for Security and Cooperation in } & 50 \text { European countries (out of 57) } \\ \text { Europe (1975) } & 28 \text { European countries (out of 30) } \\ \text { North Atlantic Treaty Organization (1949) } & \end{array}$




\section{Emerging Depictions of 'Europe' and 'Brussels'}

The European integration process and its identity are beginning to figure in creative literature and other media, even becoming the theme or the subject of particular works. (NB. As stressed in the introduction, this article is not based on an empirical survey and concentrates mainly on Anglophone literature.) A first distinction should be made between depictions of Europe (the continent in all its variety) and 'Europe', meaning the European Union. A similar distinction should be made between Brussels and 'Brussels'. 'Europe' and 'Brussels' first started to appear in creative literature as the backdrop to conventional genre-writing. (See de Berlaymont, 2018, p. 95, for a definition of these distinctions.)

Thus, for example, Peter May's 1981 The Man With No Face is straight out of the crime thriller genre, but is set in Brussels as well as 'Brussels' and several of its protagonists (a journalist, a corrupt minister) are involved in 'Europe'. May's wintry Brussels has, 'streets where once German tanks had rolled in from the east,' but is now 'being rebuilt, adapting to a new world. The hammers of the demolition workers smashing down the past...' (May, 1981, p. 25) One of his protagonists sees the European Commission, 'as a great, slow-moving machine whose purpose was simply self-perpetuation, self-justification. The Brave New World had never emerged and, he believed, never would.' (Ibid., p. 43) So far, so Eurosceptical but, after May has set the gloomy scene (including a fascinating contemporary description of how the Commission's press briefings worked in the 1970s), 'Europe' and 'Brussels' almost entirely disappear from what becomes a standard thriller about a hard-bitten, hard-drinking journalist in search of love and redemption while dodging bullets from a hired assassin.

In 1987 Stanley Johnson (father of the current UK Prime Minister), like May, uses the corrupt politician trope - this time a European Commissioner. Unlike May, Johnson sets his story squarely in 'Europe' and 'Brussels'. The quintessential insider (he was then a Commission official), but also a passionate environmentalist and a part-time novelist with several thrillers under his belt at the time, Johnson spins a tale of industrial greed, government corruption and criminal environmental destruction leading also, like May's story, to an assassination attempt and cover-ups. Johnson was too much of an insider to avoid the traps of exposition or show-don't tell but, then, he was probably writing mainly for a captive audience in the 'Brussels' policy-making community who would have recognised themselves in some of the sketches with more or less pleasure (an Italian-origin Advocate-General in the European Court of Justice is called Ernesto Pantaloni - that is, 'trousers'). Menasse (below) would later use the same technique.

Johnson's was probably the first full-length novel to be set fully in 'Europe' and 'Brussels'. (It was also the first (and, so far, only) work to become a full-length feature film. The Commissioner (1998), starring John Hurt in the lead role and directed by George Sluizer, was entered into the $48^{\text {th }}$ Berlin International Film Festival but not well reviewed.) Johnson's original work was a harbinger in two senses. First, its theme illustrated the fact that 'Europe' was becoming a regulatory giant where major world economic interests were at stake. (Much later to be convincingly documented by Anu Bradford in her 2020 The Brussels Effect: How the European Union Rules the World.) Second, it showed that 'Europe' was also becoming an important player in the field of environmental politics. In these ways and others, Johnson's book was saying, 'Europe' mattered and, subliminally, likened 'Brussels' to Washington, D.C..

Around the same time, 'Europe' and 'Brussels' started to become attractive as a backdrop, or as a hook, for televisual projects. In 1990, for example, a detective series set in Brussels, TECX, aired on British television channel ITV. A British wine importer, a French drifter and an Italian lawyer form a Brussels-based detective agency and solve a case in each of thirteen episodes set in and around 'Brussels', with the European Commission's distinctive Berlaymont headquarters building frequently reminding the viewer where the action was taking place. And in the same year British television channel BBC One aired a drama film, The March, directed by David Wheatley and starring Juliet Stevenson in the lead role as a European Commissioner. The plot concerned a charismatic Sudanese Muslim leader who takes 250,000 Africans on a march towards Europe, chanting the slogan, 'We are poor because you are rich.' Both projects were soon forgotten - the latter perhaps less fairly (it can still be found on You Tube), but both were also harbingers. The subliminal message of the former was also that 'Brussels' was becoming like Washington, D.C., and of the latter that 'Brussels' and 'Europe' had come to represent Western privilege and therefore were targets for protestors.

As with The March, creative writing about Europe began responding to events around it. Thus, David Greig's play, Europe, first performed in 1994, is clearly a dystopian extrapolation from the Balkans conflict of the early 1990s. On the one hand, Europe will be, 'Steel and tracks and trains like blood muscle and arteries holding the continent together.' (Grieg, 2002, p. 53) But, as Katia, one of his protagonists, establishes early on, her real Europe is, 'Snipers on the rooftops, mortars in the suburbs and you said: "This is Europe ... we must stay in Europe." So we stayed, even after the food ran out: "This is Europe." (Ibid., p. 30) Greig's play extrapolates from a real regional conflict. The prejudices that drive Katia from her small town ('the sort of place people come from. Not the sort of place they go to' (ibid., p. 42) and the prejudices in the small town where she and her father are marooned as refugees ('they invented hate in places like this' - ibid., p. 29) are identical, and their fates as 'foreigners' will be the same. 
This essay should perhaps also mention in passing a number of 'novelty' projects of one sort or another. An early example, Daphne Du Maurier's 1972, Rule Britannia, uses UK fusion with the US (as opposed to accession to the EU) as its tongue-in-cheek background ('such a ridiculous name, USUK...' - p. 48) Mention should also be made of the growing phenomenon of former EU officials publishing (mostly some sort of self-publishing) Eutopian novels that are more or less based on their experiences, or on their beliefs, or on both (for example: Hélin, 2009; Guggenbühl, 2010; Hick, 2013). These rarely gaze to anything other than the future they believe in - which is, of course, their right. And one should also mention the slick, wink-of-an-eye, references in passing in such works as Ian McEwan's 2019 Uchronia, Machines Like Me: And People Like You, when Prime Minister Tony Benn, elected on a majority of 162, promises to take the UK out of the EU without a referendum or Black Mirror's episode, 'Smithereens', where Prime Minister Callow is about to meet with EU negotiators in Brussels (a not-too-prescient Uchronic scenario!). In the 2017 satirical War Film, even Eurocontrol gets an oblique (and unflattering) reference when Brad Pitt's General Glen McMahon declares forthrightly, 'Listen, we are the fucking US military. We practically invented everything and now we have some chinless fuck in Brussels who's telling us we can't fly our own plane because of a volcano...'

As this review has suggested, there have been many other creative books, stories and films depicting 'Europe' and 'Brussels' in one way or another since the 1990s - mainly, but not only, in the anglophone world. A comprehensive survey is impossible but three recent works illustrate well the way in which the literary field has become increasingly rich and less genre driven. In Dutch author Ilja Leonard Pfeijffer's metaphorical Grand Hotel Europa (2018), a writer takes residence in an illustrious but decaying hotel, where he reflects on travels with a past love in various European locations and where 'so much history resides that there is no place left for a future'. In his Uchronic Civilisations (2019), French author Laurent Binet imagines a world in which Christopher Columbus's expeditions to the New World fail and Europe is successfully invaded by the Incas, who land at Lisbon. Europe becomes the New World. Lastly, in Italian author's Giuseppe Porcaro's Disco Sour, we read the 'existential odyssey of a heartsick politician to save a war-torn, post-austerity Europe from algorithmic autocracy.' (As the back cover blurb declares.) Porcaro's novel brings together, first, the dystopian vision of a tech surveillance threat to democracy with, second, the utopian vision of potential European democratic governance overcoming nation states and, third, the Uchronia of a European-wide civil war following a 2008 financial crisis.

\section{Three Case Studies: Brian Aldiss's Super-State; Dave Hutchinson's Europe in Autumn; Robert Menasse's the Capital}

Thus, 'Europe' has increasingly figured in creative writing of various sorts and in various genres, including dystopias. (But surprisingly few U/Eutopias. The academic journal, Utopian Studies, for example, published regularly since 1987, has carried many articles about the authors covered in Section 3.4, but not a single article about a European or an EU-level U/Eutopia or Dystopia.) This section will look at three works that set out dystopian futures for 'Europe'. What interests is not so much that dystopian European futures have, at last, started to emerge in European creative fiction but rather the sorts of dystopias that have been emerging.

Brian Aldiss (1925-2017) was a prolific (British) science fiction writer. His 2002 flawed Eutopia (which could also be classified as a Utopian satire), Super-State: A Novel of a Future Europe, is supposedly set 'some forty years from now'. As the title suggests, the European Union has become a super-state, led by an amoral President, Gustave de Bourcey, whose country residence, outside Brussels, is called 'Palais San Guinare' ('sanguinare' meaning 'bloody' in French). 'Rules and regulations,' Aldiss ironizes, 'originate from democratic committees in Brussels.' Despite the close attentions of the Government's Department of Social Economics, the EU is threatened from within by Muslim revolutionaries (they kidnap his daughter, who soon develops Stockholm syndrome) and New Age anarchists ('Insanatics') who have found a way to post online anonymous critical reflections about the regime. De Bourcey is hellbent on 'an adventure in the East', planning a unilateral surprise attack on Tebarou, a former colony, sinisterly musing that, 'once the state was at war, they could enforce (domestic) security measures without explanation. They could clamp down on all sorts of subversives - the Insanatics, for instance, with their dreary unpatriotic messages. And on what he termed 'the traitors within the gates." (Aldiss, 2002, p. 100) An impending sweetheart trade deal would be enough to keep China out of the war, he calculates. Meanwhile, US President Regan Bonzelli tries to tempt De Bourcey and the Chinese President, Cheng Hu, to buy into a mission to Jupiter's moon, Europa.

Acting under De Bourcey's instructions, EU forces have already sunk a ship carrying some 4,000 innocent Tebarese off the heel of Italy, pretending the ship was a threat. Now, a small EU Rapid Reaction Force hopes to take Tebarou's reformist President by surprise, backed up by precision attacks from SS20 fighter bombers. The plot elements set out here form the backdrop for a decadent society drama in which Aldiss skewers the weaknesses and foibles of his characters. The effects of climate change loom large. Aldiss magics up the deus ex-machina of a trans-Atlantic tsunami. There is science fiction, but it is worn lightly; there are thinking androids and that manned mission to Europa, leading to an unfortunate first alien encounter in which the starving crew of the Roddenberry (a nod to Gene Roddenberry, the creator of the Star 
Trek television series) eat all of the extant life on Jupiter's moon. Aldiss had a lot of fun with his construct but, evident latent Euroscepticism aside, was making some serious points. As I have argued elsewhere, citing Aldiss's vision, 'Can one imagine the EU, qua EU, invading a territory? As the US has known for a long time, with strength comes responsibility, and with responsibility come hard choices.' (Westlake, 2020, p. 261)

In 2014, Dave Hutchinson (1960- ), a British science fiction writer, published the first of four dystopian novels, Europe in Autumn, in what was to become his 'Fractured Europe' sequence. In Europe in Autumn, the European Union still exists, and is still vociferous at the UN, but the formerly integrated structures have fragmented, 'back into the eighteenth century.' (Hutchinson, 2014, p. 18) Hutchinson describes how the collapse came about: 'The early years of the twenty-first century brought a symphony of slamming doors. Economic collapse, paranoia about asylum seekers - and, of course, GWOT, the ongoing Global War on Terror - had brought back passport and immigration checks of varying stringency, depending on whose frontiers you were crossing. Then the Xian Flu had brought back quarantine checks and national borders as a means of controlling the spread of the disease... It had effectively killed Schengen and kicked the already somewhat rickety floor out from under the EU.' (Ibid., p. 27)

The result is a Continent 'alive with Romanov heirs and Habsburg heirs and Grimaldi heirs' and 'pocket nations' and 'thousands of microethnic groups' and city states. (Ibid.) The Independent Silesian State of Hindenberg even changes the state's railway gauge to make travel more difficult. (Ibid., p. 28) In a reverse echo of Section 1.4 above, the TransEurope Rail Route, 'the last great civil engineering project of the European era' becomes a metaphor for the EU's over-reach, the Company established to build it becoming, 'a microcosm of the increasingly fractious European Parliament, complete with votes, vetoes, lobbying, corruption and all the other things so beloved of democracies.' (Ibid., p. 51) Year by year, 'the Line crept across the face of Europe, at about the same time that Europe was crumbling around it.'(Ibid.)

It is a glorious and witty backdrop against which to set what is essentially a futuristic speculative espionage thriller about an enigmatic people-smuggling business, one of whose members declares, 'I like to think that I am keeping alive the spirit of Schengen.' (Ibid., p. 75) Like Aldiss, once Hutchinson has set his scene, he moves on to the story proper, but remnants of the old EU frequently drift into view. In Greater Germany, for example, the police 'were legendary for their adherence to the old EU laws on vehicle safety.' (Ibid., p. 112) Like Aldiss, Hutchinson had a lot of Eurosceptical fun with his construct but, similarly, he was making some important points about the EU's inherent potential weaknesses. (Europarama has published an online interview with Dave Hutchinson in which he explains the origins of his vision, but readers should be warned that it includes a number of plot spoilers! https://europarama.simplecast.com/episodes/europe-at-dawn-feat-dave-hutchinson)

In 2017, Austrian novelist Robert Menasse published his Uchronic novel, Die Haupstadt (The Capital). The English translation (by Jamie Bulloch) was published in 2019. Described by Konstantin Richter in Politico as 'The first great EU novel' and, a little more prosaically, by Mark Lawson in the Guardian as a 'first-class satire on EU bureaucracy', this 'baggy book' is, at one and the same time, a literary novel (with one reviewer mentioning Balzac), a detective thriller/murder mystery, and a political satire. It is peopled variously by bureaucrats, detectives, academics, lobbyists and Holocaust survivors of many European nationalities. There is also a mysterious stray pig and a riff about agricultural porcine interests. (For most denizens of the real 'Brussels' the acronym 'EPP' stands for the European People's Party; in The Capital it stands for 'European Pig Products'.)

Menasse takes a leaf out of the books of May and Johnson by setting his convoluted plots both in 'Europe' and Europe and 'Brussels' and Brussels. Like May, but unlike Johnson, Menasse was an outsider who came to Brussels and diligently undertook research. Unlike May, but like Johnson, Menasse tends to tell rather than show, giving his descriptions of the 'Brussels' policy-making community and its institutions a feeling of familiarity, although not of complete accuracy. Like Aldiss's 'rules and regulations' and Hutchinson's 'car safety regulations', Menasse pokes fun at the EU's regulatory instincts, having one character memorably declare that, 'These long johns already comply with the new EU guidelines for underwear. ... Yes, monsieur. I was surprised too. ... It's to do with the flammability of the underwear. It's all regulated now.' (Menasse, 2019, p. 95)

More deeply, Menasse, clearly, has been a 'man on a mission' for a long time. He is a European idealist who has drunk deep at the well of Jürgen Habermas's vision of European federalism. As such, the novel is bent to his cause. A key observation in the story is that, 'The Union was threatening to break apart.' (Ibid., p. 192) Echoing Denis Hay's historical account in Section 1.1 above, 'A British Professor of cultural sciences at Cambridge University said that the fundament of unified Europe was Christianity, and today we were seeing this single unifying factor disappearing both at a socio-political level and from individual behaviour.' (Ibid., p. 232) One of the (improbable) main plot lines concerns an official's plan to celebrate the fiftieth anniversary of the establishment of the European Commission by assembling all the still surviving inmates of Auschwitz, and one of Menasse's protagonists then calls for Auschwitz to be declared the capital of the European Union. 
Menasse necessarily uses the Uchronic form. In the first place, The Capital takes place in an alternative near-contemporary world (the fiftieth anniversary of the establishment of the European Commission took place just nine years before the original publication of the novel). More importantly and significantly, though, Menasse puts words never spoken in real people's mouths. Menasse writes 'in the words of Jean Monnet': 'All our efforts are the lessons of our historical experience: nationalism leads to racism and war, and with dire logic to Auschwitz.' (Ibid., p. 237) But Jean Monnet never said that; they are the words of Robert Menasse. In reality, Monnet was, as seen above, a European integrationist long before the Second World War. No doubt he found racism, and anti-Semitism in particular, repugnant and shameful, but his pronouncements were primarily about peace and the avoidance of war. Menasse, on the other hand, needs his fictitious, Uchronic, Monnet, and Europe more generally, to accept a common responsibility for the Holocaust.

There are some recurring themes and motifs in the three sample works considered above. A first, familiar to all readers of post-apocalyptic literature, is the use of cataclysms as cathartic enablers, whether war and tsunamis (Aldiss), or a financial crisis and a flu pandemic (Hutchinson) or the Holocaust (Menasse). So far, so generic. Beyond that are the classic riffs of identity and identities, fragmentation and implosion, anarchy and authoritarianism, xenophobia and the menace, in one way or another, of invading hordes (or the pretence of them). More significantly, perhaps, is the important role played by Krakow in the Hutchinson Dystopia and the Menasse Uchronia. The city was the official capital of Poland until 1596, was European capital of culture in 2013, and is a UNESCO World heritage Site. But, perhaps of more relevance, the city was also the capital of the Distrikt Krakau of the German General Government during the Second World War and the Auschwitz-Birkenau concentration/death camp complex was established just some 50 kilometres south-west of Krakow.

\section{What Might Europe's Emerging Dystopian Futures Tell us About Europe's Present?}

Dystopian treatments of Europe's future may only have started to emerge over the past thirty years, but some general characteristics are already discernible. The fundamental point is that Europe has history or, rather, it has histories ancient Greek civilization, the Roman Empire, the Holy Roman Empire, Napoleonic Europe, the Austro-Hungarian Empire, the failed Reich - and is afraid of returning to them or - perhaps more to the point - a repeat of the consequences of their collapses (for after the Roman Empire came the Barbarians, after the Holy Roman Empire came Napoleon, after the Austro-Hungarian Empire came nationalisms, anti-Semitism, Fascism and Nazism, and after the latter came the long division of Europe). The so-called 'Concert of Europe' gave way to the charnel houses of 1914-18 and 1939-45. In other words, however they may be dressed up, to the extent that they so far exist, Europe's dystopian futures are, mostly, re-visitations of its pasts, or the collapses of its pasts. Collectively, they are a variation on what Jacques Derrida called 'hauntology' or 'hauntism' or 'revenants' (Derrida, 1994, p. 20), though the 'specter' Derrida was referring to was the Marxist one of communism; 'It is only a specter, seemed to say these allies of old Europe so as to reassure themselves; let's hope that in the future it does not become an actual, effectively present, manifest, non-secret reality.' (1994, p. 46) They speak to a fear that what Europe has lived, it might live again; that what was in us might yet return; that what we did we may do again; that what we were may be what we become again. These are Europe's dystopian futures. Perhaps these are truisms - don't we always write about what we know (or about what we know we don't know)? But it seems that, when European dystopian authors seek to portray a Europe of the future, they portray it as a return to its past, or one of its pasts.

When Menasse's protagonist and possible alter ego, Professor Alois Erhart, argues in The Capital that the European Union's new capital city should be built at Auschwitz, it is because he believes that this would be the only way to prevent Europeans forgetting about one of their pasts - thus preventing it from becoming one of Europe's futures. From that point of view, one of the most significant passages in The Capital is an imagined Council (of the European Union) working party memo: '(Germany) queried the idea of Auschwitz as the fundament of European unity and stressed that the Muslims in Europe must not be excluded from the venture of European integration.' (Menasse, 2019, p. 373) This is, literally, playing with history: building a Uchronia as a better basis for Europe's future (or to argue for that future).

Are not, indeed, these representations of the perceived problem posed by an 'unintegrated' Muslim population, or the so-called 'Eurabia' threat (Brown, 2019), echoes of Christendom's centuries-old fears of invasion and subjugation by non-Christians? From Michel Houellebecq's 2015 satire, Soumission, to Murray's 2017 polemic, The Strange Death of Europe, the vision is one of Islam not just at the gates of the city but taking control. These take us back to Denys Hay's charting of the course of Europe as a Christian concept and entity. In this version of Europe's past, the 'Western' victories at the 732 Battle of Tours and the 1529 Siege of Vienna (and the semi-siege of 1532) are depicted as having 'rescued' Europe from a hideous fate (somehow overlooking the fact that, in the year 1000, some five million of Iberia's seven million inhabitants were Muslims and that, for centuries, large swathes of Spain, Portugal and Sicily prospered under enlightened Muslim rule). Consider this passage from Brian Aldiss's 2003 Super-State: 'In these endeavours (Europe's idealists) had been amazingly successful, and their hopes largely fulfilled. "But now all the endemic xenophobia is directed against other peoples, outside the EU," Paulus told his partner. "And like an echo it comes back to us." "But the Arabs are so sinister," said Ruth. "They frighten me. They are alien to us, you must admit." (Aldiss, 
2003, p. 74)

The 1990 The March was, after all, about a charismatic Muslim leader from the Sudan who leads 250,000 Africans towards Europe. A recent study prescriptively argues: 'We have no choice but to go back to fundamentals, in particular to those of European liberalism as well as what remains of its Christian heritage. We must go back to the foundations of the initial European project, beyond its bureaucratic systems. Ultimately, Europe is the only entity in which it remains possible to instil some spirit.' (Roy, 2019, p. 154)

Deliberately or not, the literary creations considered in this essay hark back to Europe's pasts, whether anti-Semitic or Islamaphobic, whether authoritarianism/dictatorship or anarchy, whether decadent monarchies or fragmented principalities. Perhaps it was these pasts that led Francisco de Boria Lassheras to write bleakly that, 'Europe is progress and civilisation. But it is also suicidal geopolitics played out like a Viennese imperial ballet, the classicide of the gulags and the genocides of Treblinka and Srebrenica. If the ghosts of the past return, it is because they never truly went away.' (de Boria Lassheras, 2015) As Florent-Claude Labrouste, the protagonist in Michel Houllebecq's latest novel, Seretonin declares, 'It isn't the future it's the past that kills you, that returns and nags and undermines you and finally kills you.' (2019, p. 280, author's translation) What Europe's emerging dystopian futures reveal is that Europeans, including Aldiss, Hutchinson and Menasse, suspect or, in Menasse's case, suggest, that Europe's pasts, or a failure to remember them, might kill its future.

\section{Acknowledgements}

A first draft of this article was presented at a 2-3 September 2019 Conference at the University of Plymouth, UK, on 'Forming the Future'. I am grateful to the organiser, David Sergeant, and the participants in that conference for their comments and suggestions. I am grateful to Celia Williams (Tamar Temptations) for initial inspiration, to Matthew Grey, Giuseppe Porcaro, Sebastian Remøy, Deborah O'Donoghue and Godelieve Vandamme for having read and commented on a later draft and to the anonymous referees for their constructive criticism.

\section{References}

Aldiss, B. (2003). Super-State: A Novel of a Future Europe. London, Orbit.

Anastasiadou, I. (2011). Constructing Iron Europe: Transnationalism and Railways in the Interbellum. Amsterdam; Amsterdam University Press. https://doi.org/10.1515/9789048515370

Binet, L. (2019). Civilizations, Paris; Bernard Grasset.

Bradford, A. (2020). The Brussels Effect: How the European Union Rules the World. Oxford, Oxford University Press. https://doi.org/10.1093/oso/9780190088583.001.0001

Brown, A. (2019). The myth of Eurabia: how a far-right conspiracy theory went mainstream. The Guardian, 16 August. https://www.theguardian.com/world/2019/aug/16/the-myth-of-eurabia-how-a-far-right-conspiracy-theory-went-mai nstream

De Berlaymont, J. (2018). Working for the EU: How to get in. London; John Harper Publishing.

De Boria Lasheras, F. (2015). The battle of Europe's utopias. European Council on Foreign Relations (blog piece), 28 January, at: https://www.ecfr.eu/article/commentary_the_battle_of_europes_utopias310895

Derrida, J. (2012). Specters of Marx: The state of the debt, the work of mourning and the new international. Routledge. https://doi.org/10.4324/9780203821619

Du Maurier, D. (1992). Rule Britannia. Arrow Books, London.

European Parliament. '100 (2020). Books: Denis https://www.europarl.europa.eu/100books/en/detail/106/europe-the-emergence-of-an-idea

Flannery, T. (2019). Europe: The First 100 Million Years. London; Penguin Books.

Grieg, D. (2002). Europe, London; Methuen, and Drama Online at: https://www.dramaonlinelibrary.com/plays/europe-iid-14228

Guggenbühl, D. (2010). Arsène au Berlaymont: roman, La Roche-en-Ardenne; éditions eole.

Hay, D. (1957). Europe: The Emergence of an Idea, Edinburgh; Edinburgh University Press

Hélin, W. (2009). L'enfant de Berlin, la vie tumultueuse de Maximilien Ebert, Nice; France Europe Editions

Hick, A. (2013). What Goes Around Comes Around, London; Austin Macauley Publishing

Houellebecq, M. (2019). Seretonin, Paris; Flammarion

Hutchinson, D. (2014). Europe in Autumn, Oxford; Solaris 
Johnson, S. (1987). The Commissioner, London; Century.

Lipgens, W. (ed.). (1985). Documents on the history of European integration. Vol. 1: Continental plans for European union 1939-1945, Berlin; de Gruyter for European University Institute, Florence.

Lipgens, W. (ed.). (1986). Documents on the history of European integration. Vol. 2: Plans for European Union in Great Britain and in exile 1939-1945, Berlin; de Gruyter for European University Institute, Florence

May, P. (2018). The Man with No Face, London; Quercus

Mazower, M. (2014). Governing the World: The history of an idea from 1815 to the present, London; Penguin Press, London

McEwan, I. (2019). Machines Like Me: And People Like You. London; Jonathan Cape

Menasse, R. (2019). The Capital. Maclehose Press, London; Quercus

More, T. (1965). Utopia, London; Penguin Classic

Murray, D. (2017). The Strange Death of Europe: Immigration, Identity, Islam, Bloomsbury, London

Nicolaïdis, K., \& Howse, R. (2002). 'This is my EUtopia...': narrative as power. JCMS: Journal of Common Market Studies, 40(4), 767-792. https://doi.org/10.1111/1468-5965.00397

Paye, S. (2010). Standardising European railways: a supranational struggle against persistent national languages and emergent local dialects. Flux, (1), 124-136. https://doi.org/10.3917/flux.079.0124

Penn, W. (1912). An essay towards the present and future peace of Europe. American Peace Society.

Pfeijffer, I. L. (2019). Grand Hotel Europe. London; $4^{\text {th }}$ Estate (forthcoming).

Porcaro, G. (2018). Disco Sour. London; Unbound.

Prestwick House. (2015). 'Why teach dystopian literature?'; https://www.prestwickhouse.com/blog/post/2015/06/why-teach-dystopian-literature

Renouvier, C. (1876). Uchronie (L'Utopie dans l'histoire), esquisse historique apocryphe du développement de la civilisation européenne tel qu'il n'pas été, tel qu'il aurait pu être, Paris ; Bureau de la critique philosophique.

Roy, O. (2020). Is Europe Christian?, London; Hurst \& Company

Salmon, T., \& Nicoll, W. (1997). Building European Union: A documentary history and analysis, Manchester; Manchester University Press.

Sargent, L. T. (2016). Utopian Literature in English: An Annotated Bibliography from 1516 to the Present. University Park, PA: Penn State Libraries Open Publishing, 2016 and continuing.

Shonfield, A. (1973). Europe: Journey to an Unknown Destination. London; Allen Lane.

Turner, P. (1965). 'Introduction,' in Thomas More, Utopia.

Westlake, M. (ed.). (2020). The European Union's New Foreign Policy. Cham, Switzerland; Palgrave Macmillan.

Wheatley, D. (1990). The March, a British drama film made for BBC One: https://genome.ch.bbc.co.uk/c0c7061c32ab427ba15e497d99fc2831

Zielonka, J. (2013). Europe's New Civilizing Missions: The EU's Normative Power Discourse, Journal of Political Ideologies, 18(1).

\section{Copyrights}

Copyright for this article is retained by the author(s), with first publication rights granted to the journal.

This is an open-access article distributed under the terms and conditions of the Creative Commons Attribution license (http://creativecommons.org/licenses/by/4.0/). 